University of Wyoming College of Law

Law Archive of Wyoming Scholarship

$1-28-2019$

\title{
Of Metaphors and Magic Wands: Are Corporations Really People?
}

Kenneth D. Chestek

University of Wyoming College of Law, kchestek@uwyo.edu

Follow this and additional works at: https://scholarship.law.uwyo.edu/faculty_articles

\section{Recommended Citation}

Chestek, Kenneth D., "Of Metaphors and Magic Wands: Are Corporations Really People?" (2019). Faculty Articles. 40.

https://scholarship.law.uwyo.edu/faculty_articles/40

This Article is brought to you for free and open access by the UW College of Law Faculty Scholarship at Law Archive of Wyoming Scholarship. It has been accepted for inclusion in Faculty Articles by an authorized administrator of Law Archive of Wyoming Scholarship. 


\title{
Of Metaphors and Magic Wands: Are Corporations Really People?
}

\author{
Kenneth Chestek*
}

\section{Table of Contents}

I. How did we get here? .................................................... 11

a. How corporations became people ............................ 11

b. How money became speech ........................................ 15

II. "Corporations are people" is not a proper legal fiction........... 17

III. Metaphor or metonym? ............................................. 25

a. The metonym of money as speech ............................ 25

b. The power of metaphor ......................................... 26

c. Breaking free from bad metaphors: The theory of OODA ..................................................................... 30

d. Rethinking the metaphors ......................................... 34

IV. Finding better metaphors............................................ 37

a. Corporations are tools......................................... 38

b. Money is a megaphone........................................... 44

V. The first step to solution: a constitutional amendment ......... 45

\footnotetext{
* Professor of Law, University of Wyoming College of Law. The author is also co-founder, and currently Chair, of a Wyoming political action committee known as Wyoming Promise, a non-partisan, grass-roots organization of Wyoming citizens attempting to get a measure on the Wyoming ballot demanding an amendment to the United States Constitution declaring that corporations are not people and that money is not speech.

This article is based on a presentation by the author at TEDxCheyenne on June 9, 2017; the video of this talk is available for viewing online at https://www.youtube.com/watch?v=aU4woH9gFDI (viewed August 31, 2018). The program was also presented again live at the Sixth Applied Legal Storytelling Conference at American University in Washington, D.C. in July, 2017. The author wishes to thank professors Mark Glover, Jason Robison, Melissa Alexander, Tara Righetti, Temple Stoellinger, Lauren McClane; the Rocky Mountain Legal Writing Scholarship group; participants in the West Coast Rhetoric Scholars Workshop; and Brad Kovach and April Hughes, the organizers of the TEDxCheyenne event, for helpful comments.
} 
Washington DC (Consolidated Press, Nov. 6, 2024) - Bill Gates has been elected the $47^{\text {th }}$ President of the United States, narrowly defeating opponent Warren Buffet by slightly fewer than one billion votes.

Tuesday's Presidential election was the first since the 2022 Supreme Court decision in Corporations United v. Federal Election Commission giving corporations the right to vote, on the theory that corporations are people, too. That decision is credited with encouraging thousands of citizens to create hundreds or thousands of shell corporations, controlled by them, for the sole purpose of voting in yesterday's election.

The vote tally as of 2 a.m. this morning was approximately 231.7 billion votes for Mr. Gates, with 230.9 billion votes cast in favor of Mr. Buffet. Several third-party candidates trailed far behind with fewer than five billion votes each.

Before you dismiss this fanciful scene as a mere dystopic nightmare, consider this: Since the 14th Amendment first announced the principle of equal protection under the law for all "persons," that clause has been invoked far more often to protect the rights of corporate entities than for the freed slaves (and their descendants) for whom the amendment was designed. ${ }^{1}$ Worse

${ }^{1}$ In 1912 , one lawyer conducted a study of all of the cases between 1868 and 1912 which had invoked the Fourteenth Amendment. The study found that, in the 604 cases which turned on some provision of the Fourteenth Amendment, only 28 (less than 5\%) involved African-Americans, for whose benefit the amendment had ostensibly been adopted. (In nearly all of those cases, the racial minorities lost.) Of the remaining cases, 312 (more than half the total) involved corporations claiming the protections of the Fourteenth Amendment in order to strike down regulations businesses did not like, including minimum wage laws, zoning laws, and child labor laws. ADAM WINKLER, WE THE Corporations: How AmERICAN Businesses Won Their Civil Rights 157-58 (2018).

In a related context, a more recent study has shown that corporations have increasingly asserted First Amendment speech rights in the Supreme Court: "[n]early half of First Amendment legal challenges now benefit business corporations and trade groups, rather than other kinds of organizations or 
still, in many of the cases in which African-Americans sought protection under the 14th Amendment, they were unsuccessful. ${ }^{2}$

Corporations have gradually won more and more political rights, including the 2010 decision in Citizens United that gave them the right to spend unlimited amounts of money on political speech. ${ }^{3}$ Now that corporations have the legal authority to indirectly influence politics, how big of a jump is it, really, to allow corporations to do directly, through voting, that which they can now do indirectly?

Of course corporate voting in our elections is a silly idea, and hopefully (almost surely?) one that will never come to pass. But to recognize that corporations can be prevented from actual voting in elections is to recognize that we, the humans who invented corporations, have the power to limit corporate influence in human political affairs. Yet the Supreme Court so far has found it difficult to define where the political rights of corporations end. The notion that "corporations are people" seems to have taken such a deep root in the collective mind of the court that the court has become blind to the damage that metaphor creates in our political system. ${ }^{4}$

individuals." John C. Coates IV, Corporate Speech and the First Amendment: History, Data, and Implications, 30 Const. COMMENT. 223, 224 (2015).

2 WINKLER, supra note 1 , at 157-58.

${ }^{3}$ Citizens United v. FEC, 558 U.S. 310 (2010); see also cases discussed at infra notes 27-38.

4 The idea that "money is speech" is equally flawed. It is possible that "money is speech" is a metonym rather than a metaphor. See infra Part III-a. If "money is speech" is a metonym, it poses less of a problem because if "money" is merely a stand-in for the concept of "influence," money would be easy to regulate. Linda L. Berger, Of Metaphor, Metonymy, and Corporate Money: Rhetorical Choices in Supreme Court Decisions on Campaign Finance Regulation, 58 MERCER L. REV. 949, 951 (2007). But if, as many claim, "money is speech" is treated as a metaphor, it suffers from many of the same problems that "corporations are people" metaphor does. While the primary focus of this article is on the "corporations are people" metaphor, I will also address "money 
It is possible to take a metaphor too far. Corporations don't have the same legal rights as humans in a lot of quintessentially human ways. For example, nobody would argue that corporations have the right to marry each other, right? ${ }^{5}$ Corporations can't have children, can they? ${ }^{6}$ At least they can't adopt children. ${ }^{7}$ And if a corporation gets sick, we wouldn't provide it governmentsubsidized health care, would we ${ }^{8}$ And certainly, being inherently immortal, corporations cannot have religious beliefs. Can they? ${ }^{9}$

If you are in the habit of skipping the footnotes as you read, may I request that you depart from that habit here and read the previous four footnotes now? I'll wait.

The preceding litany is, of course, facetious-but only barely so. ${ }^{10}$ It probably is not the case that any of those legal

is speech" from time to time, including a recommendation for a new metaphor to replace it.

${ }^{5}$ Although we do allow them to merge with each other. We apparently are even okay with plural marriages for corporations. For example, Chase National Bank merged with The Manhattan Company in 1955 to form Chase Manhattan Bank; it then merged with J.P. Morgan \& Co. in 2000 to form JPMorgan Chase Bank, N.A. See J.P. Morgan Chase \& Co., in 38 InTERnATIONAL DiRECTORY OF COMPANy Histories 253 (Jay P. Pederson ed., St. James Press 2001).

${ }^{6}$ Well, they can create wholly owned subsidiaries.

7 They can only acquire other corporations and operate them as subsidiaries.

8 Unless we decide to provide it with a government-funded bailout. See, e.g., Emergency Economic Stabilization Act of 2008, Pub. L. No. 110-343, 122 Stat. 3765 (2008).

9 Unless they want to assert religious beliefs in order to avoid a law applicable to everybody else. See Burwell v. Hobby Lobby Stores, Inc., 573 U.S. 682 (2014).

${ }^{10}$ For an alternative litany discussing ways in which corporations share constitutional rights coextensively with humans, and in other contexts have more limited or no constitutional rights, see Darrell A.H. Miller, Guns, Inc.: Citizens United, McDonald, and the Future of Corporate Constitutional Rights, 86 N.Y.U. L. REV. 887, 910-11 (2011). 
concepts is expressly based upon the notion that corporations are people, but each of those concepts are entirely consistent with that metaphor. And maybe the fact that the metaphor is so familiar to us means that our guard is down just a bit... and the principles listed above therefore don't get carefully examined. Hobby Lobby gets a pass.

This article begins from the proposition that too much money in our political system is a bad thing. ${ }^{11}$ One nonpartisan group has estimated that total "independent expenditures" on political campaigns for federal offices totaled $\$ 143.7$ million in 2008, the election cycle immediately preceding the 2010 Citizens United decision; that total jumped to $\$ 1.4$ billion in 2016 (a tenfold increase). ${ }^{12}$ Most of this money is untraceable; some comes directly from corporations, while significant amounts come from individuals. But the sources are hidden because the donations generally go to corporations qualified as 501(c)(4) "social welfare" corporations ${ }^{13}$ that do not disclose the identity of their donors (these groups are frequently referred to as "dark money" groups).

\footnotetext{
${ }^{11}$ By "too much money in our political system," I mean large-dollar donations by for-profit business corporations designed to influence the election of candidates. Spending by media corporations (for example, by endorsing certain candidates on the editorial pages) pose different concerns, which are beyond the scope of this article. Likewise, "issue advocacy" (spending money to promote ballot initiatives or create general awareness of issues unrelated to endorsing specific candidates), whether by for-profit or not-for-profit corporations, likewise poses a different set of concerns which are beyond the scope of this article.

Of course, the problem of large-dollar donations is not limited to corporate spending. A number of individual or family foundation donations poses an equally large risk to the political system, by supplanting the voices of ordinary citizens with the voices of the ultra-rich. Abandoning the metaphor of "money is speech" is one way of addressing this related issue.

${ }^{12}$ Citizens United v. Federal Election Commission, OpenSeCRETS.ORG, http://www.opensecrets.org/news/reports/citizens_united.php. These numbers do not include spending on political campaigns for state offices.

${ }^{13}$ I.R.C. $§ 501(c)(4)$ (2012). Other forms of organization, such as limited liability companies, can also be used to hide the identity of donors as well.
} 
One nonprofit, nonpartisan group, Issue One, has attempted to track as many dark money donations as possible. ${ }^{14}$ Its report, "Dark Money Illuminated,"15 concludes that just fifteen dark money groups accounted for more than $75 \%$ of the dark money spent from 2010 to 2016 . The report includes a database showing the names of those dark money organizations and as many of the individual and corporate donors to those organizations as it could find. ${ }^{16}$ Most of the donors listed were large business corporations or lobbyists funded by them. ${ }^{17}$

Popular perception is that this spending is harmful; depending on how the question is asked, anywhere between 75 and 96 percent of citizens polled agree with some version of the statement that "politicians rely too much on lobbyists/corporate donations/big money, and do not listen to me."18 Not everybody

\footnotetext{
${ }^{14}$ Issue ONE, https://www.issueone.org/ (last visited Sept. 16, 2018).

15 ISSUE ONE, https://www.issueone.org/dark-money/ (last visited Sept. 16, 2018).
}

16 "Dark Money Illuminated" Issue One Database of Dark Money Donors, GOOGLE DOCS, https://docs.google.com/spreadsheets/d/1vpImNT1tSNoBWpSIg7Hx_gqG85hcM 70CJ_5DtPcIYBI/edit\#gid=0 (last visited Sept. 16, 2018).

${ }^{17}$ For example, Issue One reports that Pharmaceutical Research and Manufacturers of America, the lobbying group for major pharmaceutical companies, provided nearly two thirds of the funding for a 501(c)(4) "social welfare" organization called Freedom Path. In its first two years, Freedom Path raised $\$ 1.58$ million to support the re-election of Utah Sen. Orrin Hatch. Michael Beckel, Dark Money Illuminated, Issue ONE 3-4, https://www.issueone.org/wp-content/uploads/2018/09/Dark-MoneyIlluminated-Report.pdf (last visited Sept. 16, 2018).

18 In 2018, 75\% of respondents to a survey by The Center for Public Integrity (66\% of Republicans and $85 \%$ of Democrats) supported a constitutional amendment to overturn Citizens United. The same survey showed that $88 \%$ of all respondents want to reduce the influence of money in politics. Ashley Balcerzak, Study: Most Americans want to kill 'Citizens United' with constitutional amendment, CTR. FOR PUB. INTEGRITY (May 10, 2018, 11:45 AM), https://www.pri.org/stories/2018-05-10/study-most-americans-want-killcitizens-united-constitutional-amendment. 
agrees with this statement, of course. ${ }^{19}$ Many of those who advocate for corporate "free speech" rights do so on the theory that corporations are "made up of people." ${ }^{20}$ Aside from the

In 2017, a stunning 96\% of respondents in a Washington Post/University of Maryland poll ranked "money in politics" as the most significant factor in "causing dysfunction in the U.S. political system." In second place was "wealthy political donors" at 94\%. John Wagner \& Scott Clement, 'It's just messed up': Most think political divisions as bad as Vietnam era, new poll shows, WASH. Post (Oct. 28, 2017),

www.washingtonpost.com/graphics/2017/national/democracypoll/?utm_term=.f386213ae5aa.

In 2016, 93\% of respondents agreed that "elected officials listen more to deeppocketed donors than regular voters." Americans Say Money In Politics Is A Top Five Concern This November, IssuE ONE, www.issueone.org/wpcontent/uploads/2016/06/issue-one-ipsos-polling-june-2016.pdf (last visited Aug. 25, 2018). In 2018, 77\% of respondents agreed that "there should be limits on the amount of money individuals and groups can spend on campaigns;" in that same poll, $74 \%$ of respondents agreed that it was "very important" that large donors to campaigns should not have more political influence than other people; an additional 16\% agreed that it was "somewhat important." Bradley Jones, Most Americans want to limit campaign spending, say big donors have greater political influence, PEW RES. CTR. (May 8, 2018), http://www.pewresearch.org/fact-tank/2018/05/08/most-americans-want-tolimit-campaign-spending-say-big-donors-have-greater-political-influence/.

${ }^{19}$ See, e.g., David Freddoso, Yes, corporations are people. Get over it., WASH. EXAMINER (Apr. 5, 2017, 2:33 PM), https://www.washingtonexaminer.com/yescorporations-are-people-get-over-it; Carson Holloway, Are Corporations People?, 41 NAT'L AFFAIRS (Fall 2015), https://www.nationalaffairs.com/publications/detail/are-corporations-people.

20 See, e.g., Holloway, supra note 19 at 110 ("The rights accorded to the corporate form, [Blackstone] suggested, were granted in order to encourage cooperation among individuals with a view to socially useful ends. Without the corporate form, an association of individuals could not make binding rules to govern its members or internal structure.”). Former Presidential candidate Mitt Romney made a similar argument in defense of his infamous comment: "Corporations are people, my friend." He followed that assertion up by saying, "Everything corporations earn ultimately goes to people. Where do you think it goes?" Philip Rucker, Mitt Romney says 'corporations are people', WASH. POST (Aug. 11, 2011), www.washingtonpost.com/politics/mitt-romney-sayscorporations-arepeople/2011/08/11/gIQABwZ38I_story.html?utm_term=.9fe296bf594f. 
problem that this defense does not define what "people" the corporation speaks for, ${ }^{21}$ this argument is circular: corporations are people because a corporation is a group of people.

There are also those who argue that the problem in our political system is not too much money; it is too little money. These advocates say that in order to counter large donations from wealthy individuals and corporations from flooding the political marketplace with gigantic donations, a better answer would be to counteract that money with a flood of small-dollar donations. The recent fundraising successes of candidates like Bernie Sanders ${ }^{22}$ and Beto O'Rourke ${ }^{23}$ suggest that this may be a viable route-even though both of those candidates lost.

Another alternative is public funding of elections. The city of Seattle, Washington is currently experimenting with "democracy vouchers," in which legal residents of the city can receive a $\$ 25$ voucher which they can assign to any City Council

\footnotetext{
${ }^{21}$ See discussion infra notes 60-64.

${ }^{22}$ Clare Foran, Bernie Sanders's Big Money, The Atlantic (Mar. 1, 2016), https://www.theatlantic.com/politics/archive/2016/03/bernie-sandersfundraising/471648/. The website Open Secrets reports that Sanders raised $\$ 228,164,501$ total, of which $\$ 134,669,942$ (57.7\% of the total) was in donations under $\$ 200$ each. Bernie Sanders U.S. Senator From Vermont, OPENSECRETS.ORG, https://www.opensecrets.org/pres16/candidate.php?id=N00000528 (last visited Jan. 2, 2019).

${ }^{23}$ Open Secrets reports that O'Rourke raised $\$ 78,979,726$ in his unsuccessful 2018 run for the United States Senate. Texas Senate 2018 Race, OPENSECRETS.ORG, https://www.opensecrets.org/races/summary?cycle=2018\&id=TXS2 (last visited Nov. 4, 2019). O'Rourke claimed that the average donation to his campaign was $\$ 47$. Amber Phillips, No, Beto O'Rourke's insane $\$ 38$ million fundraising haul does not mean he can win Texas, WASH. PosT (Oct. 12, 2018, 11:37 am), https://www.washingtonpost.com/politics/2018/10/12/no-beto-orourkes-insanemillion-fundraising-haul-does-not-mean-he-can-wintexas/?utm_term=.9060ce $75577 \mathrm{e}$.
} 
candidate of their choosing. ${ }^{24}$ Voters approved a property tax to raise $\$ 3$ million to support this program; the first election for which these vouchers will be available to assign to candidates will be in February, 2019. While interesting, this idea is beyond the scope of this paper. I must confess, however, to some skepticism about the idea of democracy vouchers, since to the extent they depend on tax dollars for funding, they would seem to be susceptible to manipulation by the political interests that would have to vote to fund them. And putting more money into the system through these vouchers would likely just further escalate the arms war: corporate and wealth interests will always be able to outspend whatever tax dollars can be put into the hands of ordinary voters. Simply put, before we could reach a satisfactory solution through public funding, we would still have to solve the Citizens United problem. Meaningful campaign finance reform cannot take place so long as corporations are regarded as people with political rights equal to human beings, and so long as money is considered speech.

This article critically examines these two metaphors. It is part examination of how we got into this situation, and part thought experiment about how we can get out of it. Part I summarizes how corporations came to be thought of by the courts as "people," and how money came to be thought of as "speech." Part II summarizes, and then debunks, the oft-proffered rationale that "corporate personhood" is merely a legal fiction. It turns out it is not a proper legal fiction at all; if it were, it would be much easier to limit the reach of the concept. The "legal fiction" that corporations are people now serves as a magic wand to endow corporations with rights they would not otherwise have, and maybe don't need in order to fulfill their social purpose. ${ }^{25}$ Rather

\footnotetext{
${ }^{24}$ Democracy Voucher Program, SeatTle.Gov, https://www.seattle.gov/democracyvoucher/about-the-program (last visited Dec. $27,2019)$.

${ }^{25}$ One Harvard professor notes that the assertion (and protection) of corporate speech rights under the First Amendment is a relatively recent phenomenon. At the time of the founding, and up until the mid-20th Century, corporations
} 
than solving problems, this supposed "legal fiction" instead is creating new problems. Part III then examines the literature of metaphor and metonym in the law. It first considers, and rejects, the notion that "corporations are people" is a metonym, which is a simple (and less powerful) word substitution. Rather, this section argues that "corporations are people" is a metaphor which actually helps transfer human rights into the corporate form.

This section then addresses the question of "why is the metaphor of corporations are people so powerful and enduring?" While one thread of modern cognitive psychology suggests that, because metaphors work at such an unconscious level, they are difficult to break out of, other scholars more hopefully suggest that through conscious choice, the human mind is capable of rejecting old metaphors in favor of newer, more useful ones.

Some scholars argue that "corporations are people" because they need certain rights, most prominently property rights, in order to fulfill their legitimate functions. ${ }^{26}$ Therefore, these scholars suggest, we need to be wary of departing from that "tried and true" metaphor. Part IV suggests that a new metaphor-that "corporations are tools" - would be a more useful way of protecting the legal rights that are useful to corporations, while

did not have extensive First Amendment rights; yet even without those rights, they still provided a powerful engine for economic growth. Coates, supra note 1, at 225; but see generally KENT GREENFIELD, CORPORATIONS ARE PEOPLE TOO (AND They Should ACT LiKe IT) 6 (Yale Univ. Press 2018), where the author argues that corporations do need some (but not all) of the constitutional rights that humans enjoy, including some speech rights, in order to fulfill their social purpose.

26 See, e.g., GREENFIELD, supra note 25, at 2 . The provocative title of this excellent book is somewhat misleading, in that the author documents throughout the book the ways in which corporate interests may be at odds with the interests of some of its stakeholders, including employees, customers, and from time to time even its shareholders. For that reason, the author advocates for a more limited set of constitutional rights for corporations than those enjoyed by natural persons. See, e.g., GREENFIELD, supra note 25, at 20, 101170. 
still denying them human rights such as the right of political speech.

While the prescription in Part IV suggests that changing the metaphor would solve the problems created in our politics when courts granted corporations the same political rights as human beings, Part V takes a more practical approach. The Supreme Court is not likely to simply change the metaphor because scholars demand the change. Part V takes a brief look at the citizens' movement across the nation to amend the United States Constitution to declare that corporations are not people, thereby overturning the rationale behind Citizens United and the many other cases, before and after, which depend on the metaphor. Part V is designed to provide the legal rationale behind changing the metaphor, and to give advocates in this movement the ammunition needed to break away from the destructive metaphors that has led us to the position we now find ourselves in.

Because metaphors are so familiar to us, so unconscious, and so visceral, it is easy to put too much faith in them. And reasoning by inappropriate metaphor (like "corporations are people") can lead us to some very strange decisions.

To repurpose and rephrase a common maxim, the unexamined metaphor is not worth relying on.

\section{How did we get here?}

The twin concepts that "corporations are people" and "money is speech" have developed somewhat independently from each other. The former has a fairly long history, dating back to the nineteenth century. The latter is of more recent provenance.

\section{a. How corporations became people}

The corporations-are-people metaphor is often said to trace its origins back to the Reconstruction-era case, Santa Clara County 
v. Southern Pacific Railroad, ${ }^{27}$ when a railroad company complained that its fences were being taxed in a manner different from fences owned by property owners who were natural persons. This raised a question of equal protection under the $14^{\text {th }}$ Amendment, which provides that "[n]o State shall ... deny to any person within its jurisdiction the equal protection of the laws."28 The court reporter's syllabus reports that

Before argument[,] MR. CHIEF JUsticE WAITE said: The court does not wish to hear argument on the question whether the provision in the Fourteenth Amendment to the Constitution, which forbids a State to deny to any person within its jurisdiction the equal protection of the laws, applies to these corporations. We are all of opinion that it does. ${ }^{29}$

27118 U.S. 394 (1886).

28 U.S. CONST. amend. XIV, $§ 1$.

${ }^{29}$ Santa Clara County, 118 U.S. at 396.

There is a significant question as to whether this statement is accurate. When Chief Justice Waite purportedly claimed that "we are all of the opinion that it does," that statement can only be true if one of the Associate Justices had a recent change of heart. In Insurance Co. v. New Orleans, 13 F. Cas. 67 (C.C.D. La. 1870) (No. 7,052), decided just three years after the $14^{\text {th }}$ Amendment was ratified, Circuit Judge Woods wrote that

The plain and evident meaning of the [the $14^{\text {th }}$ Amendment] is, that the persons to whom the equal protection of the law is secured are persons born or naturalized or endowed with life and liberty, and consequently natural and not artificial persons. This construction of the section is strengthened by the history of the submission by congress, and the adoption by the states of the 14th amendment, so fresh in all minds as to need no rehearsal.

Id. at 68 .

Ten years after writing this opinion, Judge Woods was appointed to the position of Associate Justice of the United States Supreme Court by President Rutherford B. Hayes. Justice Woods served in that position from January 5, 1881 until his death on May 14, 1887. William B. Woods, OYEZ, https://www.oyez.org/justices/william_b_woods (last visited Dec. 27, 2019). 
In other words, if the report is accurate, the Supreme Court assumed (without argument) that corporations are "persons" for the purpose of its analysis. The actual opinion of the court only deals with whether the fences were properly taxed by the state (it concludes they were not). ${ }^{30}$

Santa Clara County was a case about property rights under the $14^{\text {th }}$ Amendment, and since corporations are devices for owning and managing property, perhaps the assumption that corporations are "persons" is justified for the limited purpose of deciding that case. My point is not that the case was wrongly decided; my point is that when lawyers (and courts) cite the case for the proposition that "corporations are people, too," they are misrepresenting the actual holding of the case. That question was explicitly not argued, nor decided, by the court. ${ }^{31}$ But as later courts cited Santa Clara County as authority for the notion that corporations are people too, ${ }^{32}$ it turned out that this remark by

He was therefore a serving Associate Justice at the time Santa Clara County was decided in 1886 . Whether he changed his views in the 16 years between Insurance Company and Santa Clara County is lost to history.

For a fuller description of the history of this headnote, including the role of Justice Woods and the questionable claim that "we are all of the opinion that" corporations are people, see WINKLER, supra note 1, at 149-53.

${ }^{30}$ Santa Clara County, 118 U.S. at 416-17.

${ }^{31}$ Indeed, the way the court resolved the case made the determination of the $14^{\text {th }}$ Amendment question moot. It concluded that the state had no power to include fences as part of the "franchise, roadway, road-bed, rails, or rollingstock" (things that the state had legal authority to impose taxes on). Id. at 415 . This resolution of the case does not depend on whether the owner of those fences was a corporation or not. In that sense, if the Court had made the observation that it was of the opinion that corporations were entitled to the protection of the $14^{\text {th }}$ amendment in its opinion, it would have been dicta; the fact that the observation was only recorded as an aside by the court reporter makes the observation something less than dicta.

32 See, e.g., Covington \& Lexington. Tpk. Rd. Co. v. Sandford, 164 U.S. 578, 592 (1896); Charlotte, Columbia \& Augusta R.R. Co. v. Gibbes, 142 U.S. 386, 391 (1892); Minneapolis \& St. Louis Ry. Co. v. Beckwith, 129 U.S. 26, 29 (1889); Missouri Pac. Ry. Co. v. Mackey, 127 U.S. 205 (1888); Pembina Consol. Silver Mining \& Milling Co. v. Pennsylvania, 125 U.S. 181, 189 (1888). Many lower 
the court reporter may have been the first step down what turned into a very slippery slope, indeed.

In more modern times, the notion that corporations are people too (with some political speech rights) seems to have gained a great deal of traction. For example, in First National Bank of Boston v. Bellotti, 33 the Supreme Court held that corporations do have First Amendment protection to speak in favor of or against ballot initiatives. ${ }^{34}$ In the 2010 decision of Citizens United $v$. Federal Election Commission, the right of political speech was extended to corporations by permitting them to provide direct financial support to political candidates. ${ }^{35}$ It did

courts also quickly cited Santa Clara County as authority for the proposition that corporations are people too; see, e.g., Cent. Tr. Co. of N.Y. v. W. N.C.R. Co., 89 F. 24, 31-32 (C.C.W.D.N.C. 1898); Stockton v. Balt. \& N.Y. R.R. Co., 32 F. 9, 13-14 (C.C.D.N.J. 1887); Dugger v. Mechanics \& Traders Ins. Co. of New Orleans, 32 S.W. 5, 6 (Tenn. 1895).

33435 U.S. 765 (1978).

${ }^{34}$ Discussion of governmental affairs "is the type of speech indispensable to decisionmaking in a democracy, and this is no less true because the speech comes from a corporation rather than an individual." Id. at 777 (footnotes omitted). That case also relied heavily on the metaphor that "money is speech"; see discussion infra notes 39-49.

Professor Greenfield provides a more nuanced analysis:

Corporations should receive those speech rights necessary in order to achieve their institutional and social role. That is, corporations as a class of institutional speakers should be able to speak on the questions that arise about that rule, and individual corporations should be able to speak on matters that are germane to their own business. The further afield a corporation roams from those areas of focus, the less persuasive its claim to First Amendment protection will become.

GREENFIELD, supra note 25, at 135. He then examines specific ways in which the speech rights of corporate speakers should differ from those of natural persons. $I d$.

35558 U.S. 310 (2010). This has to be the most ironically named case in modern constitutional law. The case does not protect the rights of citizens, united or otherwise. Instead, it stands for the proposition that corporations now have the 
so by overturning several prior Supreme Court cases and major portions of the Bipartisan Campaign Finance Reform Act (commonly known as the McCain-Feingold Act). The court found "no basis for the proposition that, in the context of political speech, the Government may impose restrictions on certain disfavored speakers." 36

Citizens United was not the last decision to extend First Amendment rights to corporations. In 2012, in a per curiam opinion citing only Citizens United, the Supreme Court invalidated a Montana statute prohibiting corporations from making any "expenditure in connection with a candidate . . . that supports or opposes a candidate or political party." 37 And, in an even broader win for corporate political rights, in 2014 the Court held that closely-held, for-profit corporations may assert religious freedom claims under the First Amendment. 38

\section{b. How money became speech}

The notion that "money is speech" is frequently traced to the case, Buckley v. Valeo. ${ }^{39}$ In Buckley, the Court was faced with a challenge to Watergate-era reforms contained in the Federal

right to spend unlimited amounts of money in direct advocacy for or against candidates for political office.

${ }^{36} \mathrm{Id}$. at 341.

${ }^{37}$ Am. Tradition P'ship, Inc. v. Bullock, 567 U.S. 516, 516 (2012) (holding with a 5 Justice majority and a 4 Justice dissent) (quoting Mont. Code Ann. § 13-35227(1) (2011)).

${ }^{38}$ Burwell v. Hobby Lobby Stores, Inc., 573 U.S. 682 (2014). Note, however, that the argument of the store in this case is incoherent: it actually sought to disregard the corporate form in order to assert the religious freedom of the shareholders. See GREENFIELD, supra note 25, at 10-11. The majority opinion in Hobby Lobby did not take account of this inconsistency.

39424 U.S. 1 (1976). One of the first commenters to use the term "money is speech" was Judge J. Skelly Wright of the D.C. Circuit. See J. Skelly Wright, Politics and the Constitution: Is Money Speech?, 85 YALE L. J. 1001, 1005 (1976) (criticizing the Buckley decision in its treatment of money as the equivalent of speech). 
Election Campaign Act. That Act had placed limits on individual donations to candidates; limits on the aggregate amount an individual could donate annually on campaign donations; limits on the amount of money individual candidates could donate to their own campaigns; and imposed certain reporting requirements. ${ }^{40}$ The Act also created the Federal Elections Commission. A group of candidates and political parties challenged the law as violative of their right of free speech under the First Amendment. ${ }^{41}$ The Court upheld the limitation on contributions to individual candidates but struck down the limitations on aggregate spending and spending by candidates on their own behalf as violative of the First Amendment. ${ }^{42}$

Cases decided since 1976 have reinforced the notion that money is speech. For example, in First National Bank of Boston $v$. Bellotti, ${ }^{43}$ two national banks challenged a Massachusetts statute which barred contributions or expenditures by corporations "for the purpose of . . . influencing or affecting the vote on any question submitted to the voters, other than one materially affecting any of the property, business or assets of the

${ }^{40}$ Buckley, 424 U.S. at 13.

${ }^{41} I d$. at 7-8.

${ }^{42} I d$. at 143-44. Judge J. Skelly Wright, however, points out that this conclusion is not inevitable, and in fact may be counterintuitive:

[F]ar from stifling First Amendment values, [the Federal Election Campaign Act] actually promotes them. The ceilings on giving and spending take from wealthy citizens, candidates, and organizations only certain limited political advantages totally unrelated to the merits of their arguments-advantages which all too frequently obscure the merits of the arguments. In place of unlimited spending, the law encourages all to emphasize less expensive face-to-face communications efforts, exactly the kinds of activities that promote real dialogue on the merits and leave much less room for manipulation and avoidance of the issues.

Wright, supra note 39, at 1019 (footnote omitted).

43435 U.S. 765 (1978). 
corporation." 44 The banks wished to spend money to express their views on a ballot initiative regarding a graduated income tax on individuals in the state. ${ }^{45}$

The Supreme Judicial Court of Massachusetts framed the question presented as whether corporations have First Amendment rights (essentially a challenge to the "corporations are people" metaphor). ${ }^{46}$ The Supreme Court, however, reframed the question as whether the Massachusetts statute "abridges expression that the First Amendment was meant to protect." 47 To the extent that the "expression" at issue in the case was the expenditure of money, the reframed question essentially asked whether money was protected speech. The Court held that it was. ${ }^{48}$

The "money is speech" concept seems to have passed into the received wisdom of the Court and is oft-repeated without any serious re-examination. 49

${ }^{44} \mathrm{Id}$. at 768.

${ }^{45} \mathrm{Id}$. at 769 .

${ }^{46}$ First Nat'l Bank of Boston v. Att'y Gen., 359 N.E.2d 1262, 1269 (Mass. 1977) rev'd sub nom. First Nat'l Bank of Boston v. Bellotti, 435 U.S. 765 (1978) ("[B] efore we consider the plaintiffs' various claims, we must first consider whether and to what extent corporations possess First Amendment rights.").

${ }^{47}$ Bellotti, 435 U.S. at 776.

${ }^{48} I d$.

49 See, e.g., Citizens United v. FEC, 558 U.S. 310, 339 (2010) (“Section 441b's prohibition on corporate independent expenditures is thus a ban on speech. As a 'restriction on the amount of money a person or group can spend on political communication during a campaign,' that statute 'necessarily reduces the quantity of expression by restricting the number of issues discussed, the depth of their exploration, and the size of the audience reached.' Buckley v. Valeo, 424 U.S. 1, 19 (1976) (per curiam). Were the Court to uphold these restrictions, the Government could repress speech by silencing certain voices at any of the various points in the speech process."). 


\section{II. "Corporations are people" is not a proper legal fiction}

The idea that "corporations are people" is frequently rationalized as a "legal fiction." 50 Blackstone described "legal fictions" in this way:

[F]ictions of law, though at first they may startle the student, [are] highly beneficial and useful: especially as this maxim is ever invariably observed, that no fiction can extend to work an injury; it[s] proper function being to prevent a mischief, or remedy an inconvenience, that might result from the general rule of law. ${ }^{51}$

One might ask, what "mischief" or "inconvenience" is being solved by granting corporations the right of political speech? Or does extending the "legal fiction" that far "work an injury?"52

\footnotetext{
50 See, e.g., Agley v. Tracy, 719 N.E.2d 951, 954 (Ohio 1999) ("A corporation is an entity separate and apart from the individuals who compose it; it is a legal fiction for the purpose of doing business.") (emphasis in original); Ashley v. Ashley, 393 A.2d 637, 641 (Pa. 1978) ("This legal fiction of a separate corporate entity was designed to serve convenience and justice."); Bruun v. Cook, 273 N.W. 774, 779 (Mich. 1937). Some judges also acknowledge the limits of this fiction. For example, Justice Stevens has pointed out that "[c]orporations . . . and their 'personhood' often serve[ as a useful legal fiction. But they are not themselves members of 'We the People' by whom and for whom our Constitution was established." Citizens United v. FEC, 558 U.S. 310, 466 (2010) (Stevens, J., dissenting).

513 William Blackstone, Commentaries * 43. The notion that a legal fiction cannot "extend to work an injury" has a long lineage in English law. Lord Mansfield held that:
}

Fictions of law hold only in respect to the ends and purposes for which they were invented. When they are urged to an intent and purpose not within the reason and policy of the fiction, the other party may show the truth.

Morris v. Pugh and Harwood, 3 Burr. 124, 1243, 97 Eng. Rep. 811 (KB 1761).

${ }^{52}$ Courts will disregard the "corporate fiction" when that form is used to perpetrate fraud, commit crimes, or in other circumstances. See, e.g., SSP Partners. v. Gladstrong Invs. (USA) Corp., 275 S.W.3d 444, 454 (Tex. 2008). 
The Supreme Court has described legal fictions as devices designed to "accomplish justice."53 But courts decline to extend legal fictions beyond their original purposes. ${ }^{54} \mathrm{~A}$ legal fiction is designed to correct a discrete problem, and no more. It is essentially a "little white lie."

Prof. Lon Fuller defined a legal fiction as "either, (1) a statement propounded with a complete or partial consciousness of its falsity, or (2) a false statement recognized as having utility."55

But my claim here is broader: even where the problem is neither fraudulent nor criminal (as in the case of electioneering expenditures), where the legal fiction creates "mischief" or an "inconvenience" (rather than prevent either of those things), the fiction is not doing what it was intended to do.

${ }^{53}$ See, e.g., Johnston v. Jones, 66 U.S. 209, 221 (1861) ("[The doctrine of relation] is a legal fiction, invented to promote the ends of justice. It is a general rule, that it shall do no wrong to strangers. It is applied with vigor between the original parties, when justice so requires; but it is never allowed to defeat the collateral rights of third persons, lawfully acquired.”); accord U.S. Fid. \& Guar. Co. v. Woolridge, 268 U.S. 234, 238 (1925); Kendall v. Ewert, 259 U.S. 139, 148 (1922).

54 See, e.g., S. Nat'l Bank of N.C. v. United Pac. Ins. Co., 864 F.2d 329, 333 (4th Cir. 1989) ("The legal fiction that property is located at the owner's domicile might be appropriate for taxation and similar purposes, but it is inappropriate to apply it in interpreting the blanket bond's 'on premises' proviso. . . . Legal fictions developed for other purposes simply have no relevance.”); In re Jones, 396 B.R. 638, 646 (Bankr. W.D. Pa. 2008) ("Whether a forgiven debt qualifies as gross income for federal tax law purposes is not affected by the legal fiction that the obligation is treated as satisfied under applicable state law."); In re Chalasani, 92 F.3d 1300, 1304 (2d Cir. 1996) ("Our condemnation of the use of legal fictions here-despite the established pedigree of one of them-is that this action effectively nullified one of the principal purposes of the Bankruptcy Code: allowing the debtor to begin a new life free from debt.") (citation omitted); U.S. v. An Article of Drug Consisting of 4,680 Pails, 725 F.2d 976, 982 (5th Cir. 1984) ("[W]e have dispensed with strict application of this in rem rule when a legal fiction which exists solely to effectuate the adjudication of disputes is invoked for the opposite purpose ....").

55 Lon L. Fuller, Legal Fictions, 25 ILL. L. REV. 363, 369 (1930). He also points out that "a fiction is distinguished from a lie by the fact that it is not intended to deceive." Id. at 367. More recent scholars acknowledge that nobody since has come up with a better definition. See Aviam Soifer, Reviewing Legal Fictions, 20 GA. L. REV. 871, 875-876 (1986). 
Since everybody understands that corporations are not literally people, only the second alternative definition really fits here: the claim that "corporations are people" is a clearly false statement that has utility. The question, therefore, collapses down to just this: "utility" to do what, exactly?

Some scholars have argued that the idea of "corporate personhood" is undertheorized. Prof. Miller traces the history of the theory through three phases: (a) artificial entity (i.e corporations are creations of the state and therefore can be controlled and limited by the states), (b) real entity (corporations have real existence separate and apart from the humans which created them, and therefore have rights separate and apart from their creators), and (c) aggregate entity theory (corporations are groups of people and therefore have the same rights as individual people). ${ }^{56}$ Yet these categories are sometimes used interchangeably and without rigor. ${ }^{57}$

${ }^{56}$ Miller, supra note 10, at 914-31; see also Berger, supra note 4, at 960-62.

Note that while the "artificial entity" and "real entity" theories are mutually exclusive (a corporation can be one or the other, not both), the "real entity" and "aggregate entity" theories are not mutually exclusive. That is, either can justify the granting of constitutional rights to corporations, and are sometimes offered as alternative explanations for those grants.

There are other paradigms through which one might conceptualize the existence of corporations. Professor Joseph Morrissey distinguishes between the "state entity" and "contractarian" views of corporate existence in his analysis and critiques of the Citizens United decision. Joseph F. Morrissey, A Contractarian Critique of Citizens United, 15 U. PA. J. ConsT. L. 765 (2013). The "state entity" view is essentially the "artificial entity" view described by Professor Miller: the corporation is a grantee of rights conferred by the state, and therefore subject to state control. Id. at 807. The "contractarian" view sees the corporation as a "nexus or a hub of privately structured contractual arrangements among all of [the] constituents" of the corporation, including the "shareholders, managers, customers, suppliers, employees, service providers, creditors, and even arguably the community within which the corporation is located." $I d$. at 811 . This view seems congruent with the "aggregate entity" theory described by Professor Miller.

${ }^{57}$ For example, Drew Isler Grossman points out that in his dissent in Citizens United, Justice Stevens alternatively relied on all three theories of corporate 
If corporations are artificial entities, then "corporations are people" can only be understood as an example of Fuller's second definition of "legal fiction": a false statement that is useful for some limited purpose. The same is true for the notion that corporations are real (albeit abstract) entities with real rights; we still understand that corporations are not literally people, but that fiction becomes a useful device for understanding the nature of the rights enjoyed by the abstract entity.

But the aggregate entity theory of corporate existence seems like an example of Fuller's first definition of "legal fiction"; that is, a statement propounded with complete (or at least partial) ignorance of its falsity. The falseness arises from a disregard of the purposes for which corporations are formed. A corporation is really just a device to allow the accumulation of large amounts of capital, to accomplish purposes that individuals most often cannot accomplish on their own. In its purest form, a corporation consists of shareholders who agree to pool their resources in order to engage in economic activity. The legal principle that allows for this to occur-limited liability by the shareholders - often divorces the corporate entity from the social goals that shareholders might have. ${ }^{58}$ If the purpose of the

existence. Drew Isler Grossman, Note, Would a Corporate "Death Penalty" Be Cruel and Unusual Punishment?, 25 CoRnell J. L. \& PUB. POL'Y 697, 707 (2016).

${ }^{58}$ As Professor Greenfield explained:

Corporations have asserted rights vis-a-vis the public in order to benefit the corporation narrowly, seemingly contrary to the public interest. And when corporations participate in the political sphere, their resources are brought to bear disproportionately to benefit the affluent classes, from with their management and prominent shareholders spring. Corporate treasuries - the product of contributions by all stakeholders-are used to fight on behalf of the managerial and financial elite and against others who contribute to the companies' success. Corporate money is often used to fight against minimum-wage increases, workplace safety regulations, consumer protections, and government initiatives to retard global warming.

GREENFIELD, supra note 25, at 179. 
corporation is to make money for the shareholders, without making the shareholders liable for how that money is made, the corporation is free to engage in activities that an individual shareholder might find morally repugnant (replacing human workers with robots, for example). And making money is a very different thing from political speech. Political beliefs are normative - they reflect the moral values of the individual. Corporations have no morals, beyond the imperative to make money for the shareholders. ${ }^{59}$

Or, stated another way, who is to say what the "aggregation of people" who form the corporation want? And what "aggregation of people" count? Are we to examine the shareholders as the aggregation? If so, we have to make some pretty tenuous assumptions about whether the shareholders are really paying much attention at all, given that so many shares are held by mutual funds or other investment managers on behalf of other investors; 60 that is, the actual people who receive the dividends are pretty distantly removed from understanding, or even caring, about how the corporation makes its money. ${ }^{61}$

Or should we look at the employees of the corporation as the aggregation of people whose voice is supposedly lifted up by

59 " $[\mathrm{M}]$ any corporate lawyers will tell you that '[shareholder] rights are so limited as to be almost nonexistent,' given the internal authority wielded by boards and managers and the expansive protections afforded by the business judgment rule." Citizens United v. FEC, 558 U.S. 310, 477 (2010) (Stevens, J., dissenting) (citations omitted).

60 Alicia Davis Evans, A Requiem for the Retail Investor? 95 VA. L. REV. 1105, 1105 (2009) ("[R]ecent New York Stock Exchange . . . data reveal that trades by individual investors represent, on average, less than $2 \%$ of NYSE trading volume for NYSE-listed firms. There is no question that U.S. securities markets are now dominated by institutional investors.") (footnote omitted).

${ }^{61}$ See, e.g., Peter V. Letsou, Shareholder Voice and the Market for Corporate Control, 70 WASH. U. L.Q. 755 (1992); see also Daniel J. H. Greenwood, Essential Speech: Why Corporate Speech Is Not Free, 83 IOWA L. REV. 995, 1049 (1998) ("Not all shareholders live within breathing distance of the polluting smokestack, and some of the distant ones will not care about pollution that does not affect them directly."). 
corporate speech? That seems even more unlikely than that the corporation speaks for the shareholders, since the employees are by and large viewed as an expense to the corporation. If a corporation can make more money by paying its workers less, or by replacing them with robots and machines, the corporation's focus on the bottom line puts it at direct odds with the workers. Surely, the workers cannot be the aggregation of people which this theory of corporate personhood supposedly protects. ${ }^{62}$

We are thus left with the management-the " $\mathrm{C}$ suite"-as the supposed aggregation of people to whom this theory likely refers. But their interest in increasing their income cuts against both the interest of the shareholders in receiving dividends ${ }^{63}$ and the interest of the workers in receiving continued employment and higher wages. In short, given the many diverging interests among the people with an interest in the corporation, it is literally impossible for the corporation to discern what any "aggregation of people" really wants. They all want many things, inherently conflicting with each other. ${ }^{64}$

62 It should be noted that ordinary political action committees (PACs) do not suffer from this problem. PACs, funded by voluntary donations from a group of like-minded individuals, for the express purpose of aggregating funds to make contributions to political candidates who share their values, should not be considered "dark" money. PACs are subject to robust disclosure rules, and there is no ambiguity about what they stand for. So-called "SuperPACs," which go to great lengths to hide their donors (often using the device of a non-profit 501(c)(4) corporation), should be abolished or heavily regulated.

63 " $[\mathrm{T}]$ he investor might be lured into the investment, hoping for profits, while unwittingly supporting political candidates that are unacceptable to that investor." Morrissey, supra n. 56, at 820. Professor Morrissey also debunks the notion that political contributions somehow enhance the profitability of corporations, noting that "recent studies have concluded that corporations have not been able to show a positive correlation between support for political candidates and profitability." Id. at 821 (citing studies that show corporate political spending correlates more strongly with lower profits).

${ }^{64}$ For a more thorough discussion of the problems inherent in determining who is "speaking" when a corporation engages in political speech, see Greenwood, supra note 61, at 1021-1049. 
So the corporation really cannot be a legal fiction in the sense that it is an aggregation of people wanting to speak (there are too many discordant voices that want to be heard). We are then left with the mutually exclusive possibilities that the corporation is an artificial entity, or a real one.

If the corporation is an artificial entity (an abstraction created by the state), then by definition its charter can be limited by the entity which created it. This view is archaic, having been the dominant theory of corporate existence only from the Founding to the mid-nineteenth century. ${ }^{65}$ The more modern view is that corporations are real entities with their own set of rights, independent of the humans who created them. Professor Miller writes that the "real entity theory" helped solve a number of conceptual problems with the expansion of corporations in the late nineteenth to early twentieth centuries:

Conceptualizing the corporation as a real entity, separate from its owners, helped resolve the second interpretive problem: the fact that a corporation assumed the liability of its owners for debts and torts. Because courts came to treat the corporation as a separate entity, it meant that the corporation, not the individual owners, was liable for breach of its duties. But the flipside of duty is right. Therefore, in the same way the corporation

${ }^{65}$ Miller, supra note 10, at 916. The Wyoming Constitution, drafted during that era, reflects this view:

All powers and franchises of corporations are derived from the people and are granted by their agent, the government, for the public good and general welfare, and the right and duty of the state to control and regulate them for these purposes is hereby declared. The power, rights and privileges of any and all corporations may be forfeited by willful neglect or abuse thereof. The police power of the state is supreme over all corporations as well as individuals.

Wyoming Const., art. X, § 2 (adopted 1889). 
came to have duties independent of its owners, it also came to have rights independent of them. ${ }^{66}$

It is the "real entity" theory that underlies the Citizens United decision: the corporation is viewed as a "disfavored speaker" which has been deprived of the right of engaging in "political speech."67

In sum, the notion that "corporations are people" may have begun as a proper legal fiction: it was an idea with utility in solving problems of property management. But a legal fiction should only be used to solve problems. The recent incarnation of "corporations are people" into real entity theory (i.e. giving corporations rights heretofore only granted to real people) goes beyond the need to solve property management issues and creates problems, rather than solving them. The idea that corporations are people too, is no longer the "little white lie" of a legal fiction; it has become a magic wand to create rights where none previously existed.

\section{Metaphor or metonym?}

If "corporations are people" is not a legal fiction, what is it? Two linguistic devices offer themselves as alternatives: it could be either metaphor or metonym.

\section{a. The metonym of money as speech}

Professor Linda Berger points out that the protection of corporate money as speech protected by the First Amendment requires three separate metaphors working together: (1) corporations are people, (2) money is speech, and (3) speaking is a

\footnotetext{
${ }^{66}$ Miller, supra note 10, at 923 (footnotes omitted).

${ }^{67}$ Citizens United v. FEC, 558 U.S. 310, 341 (2010).
} 
"marketplace of ideas." 68 "With those metaphors mapping the way, corporate money talks, and it is protected speech." 69

But she also points out an apparent anomaly in that formulation. If, instead of a metaphor, money is taken to be a metonym for the concept of attempts to influence elections, the result changes. Money is then portrayed as evil, a source of temptation, or corrupting, and therefore is a proper subject for regulation. 70 "Speech in the metaphorical market deserves protection; money in metonymical isolation requires regulation."71

A metaphor uses one concept to explain a phenomenon in a different domain (using the process of "mapping"), ${ }^{72}$ while a metonym uses a word as a stand-in for a different concept (no mapping needed). "Metonymy involves understanding one thing in terms of something else that is closely related to it, such as part for whole or producer for product . . .."73 Professor Steven Pinker gives the example, "Suzie is parked out back."74 Obviously, the name "Suzie" is a stand-in for Suzie's vehicle; no one actually thinks Suzie herself is stuck out back in the parking lot. Nor are Suzie's rights transferred, or "mapped," to her vehicle; conversely the characteristics of Suzie's vehicle are not imputed to Suzie herself.

The idea of "corporations are people" as a metonym can therefore be dismissed fairly easily. Mapping is clearly happening in the "corporations are people" construct. The rights and

\footnotetext{
68 Berger, supra note 4, at 950.

${ }^{69} \mathrm{Id}$.

${ }^{70} \mathrm{Id}$.

${ }^{71} I d$. at 951.

72 See discussion infra at notes 75-86.

${ }^{73}$ Routledge Encyclopedia of NarRative Theory 307 (David Herman et al., eds., 2010).

74 Steven Pinker, The Stuff of Thought: Language as a Window into HuMAN NATURE 112 (2007).
} 
characteristics of human beings are being mapped on to the artificial entity called a "corporation." That is the work of metaphor. But what about the "money is speech" piece? Has money become synonymous with "influence," such that mapping is not needed?

Viewing money as a metonym instead of a metaphor would allow the government to regulate it, as Professor Berger points out; "money is the root of all evil" seems to cry out for regulation. But if "money talks" - that is, "money is speech" is viewed as a metaphor rather than a metonym-then we still have a problem, since the impulse to protect speech will be mapped onto money.

\section{b. The power of metaphor}

Metaphors are powerful things. Professor Linda Berger describes metaphor and analogy as the "sun and the moon of legal persuasion."75 Linguist George Lakoff and philosopher Mark Johnson are probably the most well-known scholars who study the impact of metaphors on the way we think. ${ }^{76}$ They developed the theory of the "conceptual metaphor," a linking of one concept to another at such a subconscious level that the person employing the metaphor does not even perceive the metaphor. For example, most of us use metaphors such as "more is up" ("my income rose this year when I got that promotion"), or "love is a journey" ("where are we going in this relationship?"), without consciously understanding that we are using a metaphor. ${ }^{77}$

But the very power of metaphors also makes them dangerous. Amos Tversky, one of the fathers of the modern discipline of cognitive psychology, once told the audience at a

\footnotetext{
75 Linda L. Berger, Metaphor and Analogy: The Sun and Moon of Legal Persuasion, 22 J.L. \& POL'Y 147, 147 (2013).

76 See generally George LaKoff \& Mark Johnson, Metaphors We Live By (1980). Their groundbreaking work in 1980 is often credited with being the foundation of the entire discipline of cognitive psychology.

$77 I d$. at 15-16, 44 .
} 
conference at the University of Illinois: "Because metaphors are vivid and memorable, and because they are not readily subjected to critical analysis, they can have considerable impact on human judgment, even when they are inappropriate, useless, or misleading. ... They replace genuine uncertainty about the world with semantic ambiguity. A metaphor is a cover-up."78

Lakoff and Johnson agree:

The very systematicity that allows us to comprehend one aspect of a concept in terms of another . . . will necessarily hide other aspects of the concept. In allowing us to focus on one aspect of a concept . . . a metaphorical concept can keep us from focusing on other aspects of the concept that are inconsistent with that metaphor. ${ }^{79}$

This phenomenon is called "hiding." 80

Much has been written about the use of metaphor in legal reasoning and persuasion. ${ }^{81}$ Many scholars, in addition to judges,

78 Michael Lewis, The Undoing Project: a Friendship That Changed OuR MiNDS 316 (2017) (quoting Amos Tversky's statements from the University of Illinois's conference about metaphorical thinking) (internal quotation marks omitted). Cf. Greenwood, supra note 61, at 1020 (discussing Justice Powell's opinion in First National Bank of Boston v. Bellotti, 435 U.S. 765 (1978)). Greenwood also noted: "Speech, not speakers, ... is what is protected. Thus, one need not consider the speaker at all: we are relieved of that obligation of thought." Id.

${ }^{79}$ LAKOFF \& JOHNSON, supra note 76, at 10.

80 See id. at 10-11. See also Amy E. Sloan \& Colin Starger, New Wine in Old Wineskins: Metaphor and Legal Research, 92 NotRe DAME L. REV. OnLINE 1, 8 (2016) ("[W] hen our conceptual metaphors become outmoded, hiding can inhibit and constrain our thinking without our ever realizing it. In situations where conceptual change is needed to catch up with events on the ground, hidden metaphors potentially calcify thinking and stifle innovation.").

${ }^{81}$ See generally Berger, supra note 4; Linda L. Berger, What is the sound of a corporation speaking? How the cognitive theory of metaphor can help lawyers shape the law, 2 J. Ass'N LEGAL WRITING DIRECTORS 169, 170 (2004); J.

Christopher Rideout, Penumbral Thinking Revisited: Metaphor in Legal 
have recognized that because metaphors are so powerful, they have the potential to be misused. ${ }^{82}$ Judge Cardozo once wrote in an opinion that " $[\mathrm{m}]$ etaphors in law are to be narrowly watched, for starting as devices to liberate thought, they end often by enslaving it." 83

Professor Berger writes that "[i]n cognitive theory, metaphor is not only a way of seeing or saying; it is a way of thinking and knowing, the method by which we structure and reason, and it is fundamental, not ornamental." 84 In addition, she

Argumentation, 7 J. Ass'N LEGAL Writing Directors 155 (2010); David T. Ritchie, The Centrality of Metaphor in Legal Analysis and Communication: An Introduction, 58 MERCER L. REV. 839 (2007); Jeanne L. Schroeder \& David Gray Carlson, The Appearance of Right and the Essence of Wrong: Metaphor and Metonymy in Law, 24 CARDOZO L. REV. 2481, 2515 (2003); Michael R. Smith, Levels of Metaphor in Persuasive Legal Writing, 58 MERCER L. REV. 919 (2007); Elizabeth G. Thornburg, Just Say "No Fishing": The Lure of Metaphor, 40 U. Mich. J.L. REFORM 1 (2006); Steven L. Winter, The Cognitive Dimension of the Agon Between Legal Power and Narrative Meaning, 87 MiCH. L. REV. 2225 (1989); Steven L. Winter, The Metaphor of Standing and the Problem of Self-Governance, 40 STAN. L. REV. 1371 (1988).

82 See, e.g., Thornburg, supra note 81, at 1 ("In the legal setting, reliance on [a] metaphor can act as a substitute for rigorous analysis, disguising the factors that influence the result in a case. At best, it is uninformative. Worse, the .. . metaphor may itself shape the court's attitude toward the issue or claim in a lawsuit.").

${ }^{83}$ Berkey v. Third Ave. Ry. Co., 155 N.E. 58, 61 (N.Y. 1926).

${ }^{84}$ Berger, What is the sound of a corporation speaking?, supra note 81, at 170 . She based this conclusion on the work of Lakoff and Johnson. See e.g., LAKOFF \& JOHNSON, supra note 76, at 3 (noting Lakoff and Johnson first developed the theory of the "conceptual metaphor"):

Metaphor is for most people a device of the poetic imagination and the rhetorical flourish - a matter of extraordinary rather than ordinary language. Moreover, metaphor is typically viewed as characteristic of language alone, a matter of words rather than thought or action. For this reason, most people think they can get along perfectly well without metaphor. We have found, on the contrary, that metaphor is pervasive in everyday life, not just in language but in thought and action. Our ordinary conceptual system, in terms of which we both think and act, is fundamentally metaphorical in nature. 
writes that "[a]s metaphor helps us understand the unfamiliar concept, it also shapes our thoughts about the new concept because it maps on top of the new experience the structures, inferences, and reasoning methods of the old." 85 Metaphor is powerful because "[w] hat we 'know' from experience is believed more deeply than anything we learn by listening or reading. Metaphor is persuasive because it draws on tacit knowledge that has been embedded through unavoidable and repeated experience." 86

But simply observing that metaphors are powerful things does not help us understand how to break free from that power, especially when the metaphor has led to poor results. Why is it that metaphors enslave thought, and are so hard to escape?

Perhaps the theory of OODA loops can provide a possible explanation. ${ }^{87}$

\section{c. Breaking free from bad metaphors: The theory of OODA}

OODA, originally conceived for military strategy, 88 is a useful tool for analyzing the process through which any decision is made, from mundane problems to highly complex and consequential ones. ${ }^{89}$ OODA stands for:

\footnotetext{
${ }^{85}$ Berger, supra note 4, at 955 (citing I.A. RICHARDs, ThE PHILOsophy oF RHETORIC 92-94 (1936)).

${ }^{86}$ Berger, What is the sound of a corporation speaking?, supra note 81, at 176177 (citing GEORGE LAKOFF \& MARK JOHnson, PHILOSOPHY IN THE FleSh: THE EMbodied Mind AND ITs CHALlEnge to Western THOUGHT 59 (1999)).

87 Thanks to Todd Jagger of Wolf-PAC for showing me the power of OODA as an analytical tool.

88 Robert Coram, Boyd: The Fighter Pilot Who Changed the Art of War 334-35 (2002).

89 This is not the first law review article to discuss the OODA loop. See, e.g., Thompson Chengeta, Defining the Emerging Notion of "Meaningful Human Control” in Weapon Systems, 49 N.Y.U. J. INT'L L. \& POL. 833 (2017) (discussing the relative roles of humans and machines in the OODA cycle); Brandon
} 
Observe (detect the problem to be solved)

Orient (gather relevant data needed to solve the problem)

Decide (process the data according to logical and/or emotional reasoning)

Act (implement the answer which results from the Decide process)

The OODA process is cyclical; that is, it occurs in one or more sequential loops. The Action you take at the end of the process has an effect on the problem you are trying to solve. Once you Act, you must then Observe again to determine if your action (a) solved your problem, (b) did not solve the problem, or (c) solved the original problem but created a new problem to be solved. If the outcome was either (b) or (c), you must Orient yourself to the changed condition and repeat the process.

Note also that the Observe and Orient steps must be complete and accurate in order to reach a good decision. If you fail to observe the problem correctly (e.g., you fail to spot the correct issue in a case), or do not orient yourself correctly by conducting thorough and effective research, you will not solve the problem.

Every legal problem requires a series of OODA processes to resolve them. A judge Observes: a defendant has filed a 12(b)(6) motion to dismiss the case, and I must decide it. She Orients herself: she reads the complaint; reads the motion to dismiss; and reads the briefs filed by the parties; she also does her own

Garrett \& Seth Stoughton, A Tactical Fourth Amendment, 103 VA. L. REV. 211 (2017) (discussing the OODA loop in the context of police tactics); Alan L. Schuller, At the Crossroads of Control: The Intersection of Artificial Intelligence in Autonomous Weapon Systems with International Humanitarian Law, 8 HARV. NAT'L SEC. J. 379 (2017) (discussing problems when some phase of the OODA process is given to machines); Jeffrey L. Vagle, Tightening the OODA Loop: Police Militarization, Race, and Algorithmic Surveillance, $22 \mathrm{MICH}$. J. RACE \& L. 101 (2016) (discussing OODA in the context of military automated surveillance systems and techniques by civilian police departments). It is, however, one of the first articles to extend the OODA principle beyond the law of war or military-or police-related decision processes. 
research to fill in any gaps or to check the veracity of the claims made by the parties; and other activities. She then processes all of that information to Decide: motion denied. She Acts by writing an order and opinion explaining her decision.

And that act affects the lawsuit by allowing it to go forward. It creates a series of new problems to be solved: the parties will now engage in discovery, which could lead to more disputes for the court to decide. There could be a motion for summary judgment; a motions in limine or other motions to decide before trial. There could even be a trial. Every stage of the proceeding will require another OODA process, and the decision in each step will affect future behavior of the parties or create new problems to be solved.

It is not just lawsuits that use an OODA loop process. The law itself develops via an endless OODA loop; this is how the common law grows. Appellate Court A must decide an appeal. It Observes the issue or issues presented. It Orients itself by reading the record, reading the briefs of the parties, and conducting its own research. It Decides the case by applying the rules it has discovered during the orientation phase; critically, the rule of stare decisis guides the court to decide this case consistently with precedent cases. It then Acts by issuing an opinion and order.

And we now come to the crux of the problem: the decision of Appellate Court A becomes a part of the body of law that Appellate Court B will likely take into account when the next case presenting the same or similar issues arrives. Appellate Court B uses a new OODA process to decide that case, which then becomes part of the body of law that Appellate Court C must take account of, and the common law (or interpretations of statutory law) grows and changes incrementally. But if Appellate Courts B, $\mathrm{C}$ and beyond do not adequately Observe the new problems created by the Act of the previous court, then the new OODA cycle goes off course, and each new Decision and Act compound the undetected problem of the preceding courts. 
This is how corporations came to be endowed with the right of political speech. It began innocently enough, by giving corporations some rights possessed by natural humans in order to allow them to serve the functions for which they were created. Then, through a long series of decisions spanning more than 200 years, corporations gradually gained more and more rights, small increment by small increment, to the point where courts now expressly grant corporations the right of political speech. ${ }^{90}$ No court seemed to notice the inexorable accumulation of political power in already-powerful institutions, and how that power has diminished the voices of average human beings.

To some extent, this short-sightedness is baked into the doctrine of stare decisis. Under this doctrine, courts are supposed to decide each new case consistently with previous cases, deciding no more than necessary to resolve the immediate case before it. ${ }^{91}$ Departures from precedent are supposed to be rare. ${ }^{92}$

Another reason for this short-sightedness may be the power of metaphor itself. As discussed in Part III-B, ${ }^{93}$ metaphors are powerful; they can substitute for critical thinking and hide

\footnotetext{
${ }^{90}$ For an excellent and well-documented examination of the entire 200-year process through which corporations gained their "civil rights," see generally WINKLER, supra note 1.
}

${ }^{91}$ See, e.g., Wash. State Grange v. Wash. State Republican Party, 552 U.S. 442, 450 (2008) ("courts should neither 'anticipate a question of constitutional law in advance of the necessity of deciding it' nor 'formulate a rule of constitutional law broader than is required by the precise facts to which it is to be applied."') (internal quotation marks omitted). But note that the majority in Citizens United arguably did not adhere to that principle. See Citizens United v. FEC, 558 U.S. 310, 405-406 (2010) (Stevens, J., concurring in part and dissenting in part) (citing PDK Labs. Inc. v. U.S. D.E.A., 362 F.3d 786, 799 (D.C. Cir. 2004)) ("[I]f it is not necessary to decide more, it is necessary not to decide more.").

92 Arizona v. Rumsey, 467 U.S. 203, 212 (1984) (“Although adherence to precedent is not rigidly required in constitutional cases, any departure from the doctrine of stare decisis demands special justification.").

${ }^{93}$ See supra notes 75-87 and accompanying text. 
new insights. ${ }^{94}$ Metaphors can interfere with the re-Observation by hiding the effects of the preceding Act[ion].

But courts do, on rare occasions, overrule previous cases and make major changes in legal doctrine. It is well past time for the Supreme Court to make a fresh Observation: there is a serious and systemic problem with large business corporations having political speech rights. ${ }^{95}$ Much like a dystopic science fiction movie in which machines with artificial intelligence take over the world, massive, inanimate, artificial corporations are imposing their political preferences on the human beings which created them.

\section{b. Rethinking the metaphors}

So when the Supreme Court gets stuck in the twin metaphors that corporations are people and money is speech, are we doomed to a life of corporatocracy?

Psychology professor Stephen Pinker acknowledges the significant contributions that Lakoff and Johnson have made in showing the significance of conceptual metaphors to our process of reasoning. But he insists that Lakoff and Johnson "take[ the idea a wee bit too far." 96 He points out that because people don't even recognize many of the conceptual metaphors they use, they can easily transcend them. For example, the concept of a "can of worms" is a conceptual metaphor for "a profusion of problems."

\footnotetext{
94 See LEWIS, supra note 78, at 316 and accompanying text (recalling Amos Tversky's observation that "[a] metaphor is a cover-up.").

95 See GREENFIELD, supra note 25, at 23 ("The billions of dollars flooding the electoral process skew it-and the legislative process that follows-toward the moneyed and well-heeled. And the constant search for financial resources by candidates and elected officials perverts the nature of public service. The Court has been so enamored with a simplistic, libertarian theory of free speech doctrine that it is blind to those risks.") Later, he argues: "A constitutional amendment is not required to get rid of . . Citizens United. All that is required is a court more sophisticated in its understanding of free speech and less obtuse about the real-life implications of money in politics." Id. at 112.
}

96 PINKER, supra note 74, at 247. 
People don't actually visualize a can full of worms when they hear the expression; they intuitively understand that the speaker is referring to a profusion of problems. ${ }^{97}$ Thus,

[p]eople not only can ignore metaphors, but can question and discount them, and analyze which aspects are applicable and which should be ignored. Indeed, calling attention to conventional metaphors is a common genre of humor, as when Steven Wright asked, "If all the world's a stage, where is the audience sitting?"98

If Pinker is correct, we can have some hope that the Supreme Court can reason its way out of the metaphor that corporations are people. ${ }^{99}$ So let's do the critical analysis of the

\footnotetext{
${ }^{97} I d$. at 248 .

98 Id. at 249 .
}

99 There are, of course, examples where courts do ultimately reject bad metaphors and overrule the precedents that flow from those metaphors. For example, from the earliest stages of our common law until the mid-20th century, every state adhered to some form of the doctrine of sovereign immunity. The concept was derived from the notion that " $[t]$ he king can do no wrong," 1 WiLliam BLACKSTONE, COMMENTARIES *238. That formulation depends on the metaphor of "government is a king." Kings, in medieval Europe, were thought to have derived their power directly from God, so it seemed inappropriate to enable somebody to sue God. Id. at 242-243 ("[The king] owes no kind of subjection to any other potentate on earth. Hence it is, that no suit or action can be brought against the king, even in civil matters, because no court can have jurisdiction over him[,] [f]or all jurisdiction implies superiority of power. ...”); see also JOHN N. FIGGIS, THE Divine RIGHT OF KINGS 5-6 (2d ed. 1914). Ultimately, states began to see the injustice forced upon individuals injured by the acts of very human governments, so they rejected the government-is-king metaphor and began to allow people to sue their very human governments under certain conditions. See, e.g., David W. Case, From Pruett to Presley: The Long and Winding Road to Abrogation of Common Law Sovereign Immunity in Mississippi, 63 Miss. L.J. 537 (1994); see also Hargrove v. Town of Cocoa Beach, 96 So. 2d 130 (Fla. 1957) (according to Professor Case, $i d$. at 542, this was the first case to abrogate common law state sovereign immunity from torts). 
"corporations are people" metaphor for a moment, to discover which aspects of the metaphor should be ignored.

To non-lawyers, it is obvious that corporations are not people at all. Unlike human people, corporations live forever, even after their human founders die. They feel no pain. They don't require clean air or water in order to thrive. They don't appreciate beauty or aesthetically pleasing landscapes. They have no soul. And to some extent, the interests of corporations are at odds with the needs of humans. To the extent that humans perform the labor that the corporations need to produce the products they sell, the corporate incentive frequently leads the corporation to drive down wages (in order to sell products cheaper in the amoral marketplace). ${ }^{100}$ If that means outsourcing labor to low-wage countries in a different part of the world or replacing human workers with automation, the financial imperative of the market may lead the corporation to make those choices, to the detriment of the human workers. ${ }^{101}$

These outcomes are almost guaranteed so long as corporate law embraces a "shareholder primacy" view of the corporation. ${ }^{102}$ In this view, the corporation exists for the benefit of its owners,

100 GREENFIELD, supra note 25, at 179.

101 Prof. Greenfield explains:

Imagine a company facing the choice of whether to close a unionized, high-wage factory and move production to a sweatshop in a country that has no health and safety protections for workers. Shareholders will certainly prefer the change, all else being equal. The decrease in labor costs will flow to the corporation's bottom line, available for distribution to shareholders.

Id. at 197-98.

102 See, e.g., Lydia Segal, Benefit Corporations: A Step Toward Reversing Capitalism's Crisis of Legitimacy?, 24 VA. J. Soc. POL'Y \& L. 97, 100-01 (2017). The concept of "shareholder primacy" is often traced back to the seminal case Dodge v. Ford Motor Co., 170 N.W. 668 (Mich. 1919), a case which one scholar calls "the original sin" of corporate law. See GREENFIELD, supra note 25, at 3338 . 
and the duty of the board of directors is to maximize shareholder value. The needs of other stakeholders, including "technical stakeholders" (customers and employees) and "institutional stakeholders" (the environment, society at large) must be subordinated to the needs of the shareholders. ${ }^{103}$

The relatively new concept of the "benefit corporation" promises some relief from the negative aspects of shareholder primacy. A benefit corporation is "required to have a purpose of creating 'general public benefit' and [is] allowed to identify one or more 'specific public benefit' purposes."104 Benefit corporation statutes redefine the fiduciary duty of the board of directors to require consideration not only of shareholder value, but also the impacts of their decisions on employees, customers, the community, society at large, and the local and global environment. ${ }^{105}$ As of January 2016, 31 states (importantly, including Delaware) had enacted laws permitting benefit corporations. ${ }^{106}$ However, this concept still appears to be mostly a theoretical exercise that is gaining currency in business school theory more so than the law. ${ }^{107}$

It is sometimes easy to lose sight of the fact that humans created corporations to serve humans, not to exploit them. Corporations were created to allow the accumulation of large amounts of capital to build the industries and infrastructures

103 Segal, supra note 102, at 101-102.

104 William H. Clark, Jr., \& Elizabeth K. Babson, How Benefit Corporations are Redefining the Purpose of Business Corporations, 38 WM. MiTCHELL L. REV. 817, 839 (2012) (emphasis omitted). For a good discussion of why corporations "should become more like people" and how the benefit corporation model can help, see GREENFIELD, supra note 25, at 208-223.

105 Clark \& Babson, supra note 104, at 839-840.

106 Segal, supra note 102, at 112.

107 Clark \& Babson, supra note 104, at 831 ("Based on the limited case law available, courts seem reluctant to wade into ... issues [arising from statutes which allow business corporations to consider interests other than the shareholders] and often fall back on shareholder primacy."). 
that were too large or cumbersome for individuals to build. Now some of those corporations have become "too big to fail."

\section{Finding better metaphors}

It seems clear that the notion that "corporations are people" is a metaphor, not a legal fiction nor a metonym. It is not a legal fiction because it is not an uncontroversial "white lie" to solve an otherwise-intractable legal issue; ${ }^{108}$ nor is it a metonym, because it is not a simple word-association device. ${ }^{109}$ It is a metaphor because the characteristics of one system (people) are being mapped on to the new thing (the corporation). In this sense, the metaphor serves as a magic wand to endow corporations with rights just like the people they are being compared with. This is the sense in which Tversky and others claim that metaphor can replace clear thinking. ${ }^{110}$

"Money is speech" could be thought of as a metonym. ${ }^{111}$ As a metonym it is unproblematic; money can easily be regulated because it does not have any inherent rights. The problem arises if "money is speech" is viewed as a metaphor: when the characteristics of "speech" (primarily the notion that speech is protected by the First Amendment) are metaphorically mapped on to "money," problems arise: speakers with more money have more First Amendment rights than speakers with less money.

The simple solution to these problems could be to recognize that the twin metaphors need to be replaced by more useful ones. Thus: corporations are not people; they are tools created by people to accomplish business goals. ${ }^{112}$ And money is not speech; it is a

\footnotetext{
108 See supra notes 50-67 and accompanying.

109 See supra notes 72-72 and accompanying text.

110 See supra notes 75-80 and accompanying text.

111 See discussion at supra notes 68-74.

112 I am not the first to suggest this different metaphor.
}

[C]orporations, not being citizens, cannot be legitimate political actors. Like the government itself, corporations are mere tools of the citizenry, 
megaphone that can be used to amplify the speech of wealthy corporations and individuals until that speech completely drowns out the voices of people with less money. ${ }^{113}$

\section{a. Corporations are tools}

The "corporations are tools" metaphor works better because tools have specific, and limited, uses. ${ }^{114}$ You would not use a hammer to drive a screw, for example; you need a screwdriver for that job. You do not magically endow the hammer with the right to affix all forms of fasteners.

The late Justice William Rehnquist recognized the danger in giving corporations the power of political speech:

It cannot be . . readily concluded that the right of political expression is . . . necessary to carry out the functions of a corporation organized for commercial

political objects rather than political subjects, to be given just as much respect as the citizens deem useful and no more. To grant a tool a right against the citizens who use it is a form of political idolatry that ought to be abhorrent to any democratic regime. Rights are for people, not for their instruments.

Greenwood, supra note 61, at 996 (footnotes omitted).

113 While I am not aware of any other suggestion of the metaphor "money is a megaphone," Judge Skelly Wright came close to this analysis when he criticized the Buckley $v$. Valeo decision in his 1976 law review article. Wright, supra note 39, at 1006 . Judge Wright did not discuss whether this formulation was a metonym or a metaphor, but he did write that there were two options for conceptualizing campaign donations and expenditures. One would be to treat such things as "equivalent to pure speech." Id. The second alternative would be "to treat political giving and spending as a form of conduct related to speechsomething roughly equivalent to the physical act of picketing or to the use of a sound-truck." Id. Either approach (money is pure speech, or money is conduct akin to a sound truck), requires mapping, and thus are alternative metaphors.

114 This concept has been recognized by the Supreme Court beginning in the era of the Founding: "A corporation is an artificial being, invisible, intangible, and existing only in contemplation of law. Being the mere creature of law, it possesses only those properties which the charter of its creation confers upon it ...." Trustees of Dartmouth College v. Woodward, 17 U.S. 518, 636 (1819). 
purposes. A State grants to a business corporation the blessings of potentially perpetual life and limited liability to enhance its efficiency as an economic entity. It might reasonably be concluded that those properties, so beneficial in the economic sphere, pose special dangers in the political sphere. Furthermore, it might be argued that liberties of political expression are not at all necessary to effectuate the purposes for which States permit commercial corporations to exist. So long as the Judicial Branches of the State and Federal Governments remain open to protect the corporation's interest in its property, it has no need, though it may have the desire, to petition the political branches for similar protection. Indeed, the States might reasonably fear that the corporation would use its economic power to obtain further benefits beyond those already bestowed. ${ }^{115}$

In response to potential objections based on the First Amendment guarantee of free speech, Rehnquist wrote:

The free flow of information is in no way diminished by the Commonwealth's decision to permit the operation of business corporations with limited rights of political expression. All natural persons, who owe their existence to a higher sovereign than the Commonwealth, remain as free as before to engage in political activity. ${ }^{116}$

Note the implicit hierarchy that Rehnquist sets up here: God created humans, and humans created corporations. Humans cannot (or should not?) aspire to the same powers as God any

\footnotetext{
115 First Nat'l Bank of Boston v. Bellotti, 435 U.S. 765, 825-26 (1978) (Rehnquist, J., dissenting) (footnotes omitted).

116 Id. at 828 .
} 
more than corporations should aspire to the same powers as humans.

Rehnquist penned these words in the case of First National Bank of Boston v. Bellotti (1978). Unfortunately for advocates of campaign finance control, he wrote them in a dissenting opinion; the majority, in that case, granted corporations the right to spend money opposing a ballot measure, thereby cementing the metaphor that money is speech. 117 That metaphor lives on in more recent Supreme Court cases too. ${ }^{118}$

It appears that the Supreme Court has been blinded by the "corporations are people" metaphor; it cannot see that a concept which began as a legal fiction has ceased to serve justice (which is the proper function of a legal fiction), and has instead become a device for creating injustice. In this sense, the Supreme Court is like the Sorcerer's Apprentice. ${ }^{119}$ Just as Mickey tried to use magic to endow a tool (his broom) with the powers of a human being to carry water, the Supreme Court is attempting to endow a different type of tool (a corporation) with the human power to make political decisions.

But remember what happened to Mickey. He used magic to endow the broom with the power to carry water. Satisfied with his grant of human powers to his tool, he dozed off. The results, of course, were disastrous, as the broom continued to carry water

${ }^{117}$ Id. at 795. But cf. FEC v. Mass. Citizens for Life, Inc., 479 U.S. 238, 258 (1986), in which the majority pointed out that

The resources in the treasury of a business corporation, however, are not an indication of popular support for the corporation's political ideas. They reflect instead the economically motivated decisions of investors and customers. The availability of these resources may make a corporation a formidable political presence, even though the power of the corporation may be no reflection of the power of its ideas.

118 See McCutcheon v. FEC, 572 U.S. 185, 193 (2014) (holding that federal limits on how much money an individual donor may contribute in total to all political candidates violated the First Amendment).

119 The Sorcerer's Apprentice, in Fantasia (Walt Disney Productions 1940). 
long after the indoor well was full. All of Mickey's efforts to remediate the problem backfired; for example, when he tried to chop the broom into 100 fragments, each fragment grew arms and kept on carrying more and more water. Having lost control of the situation, Mickey was unable to come up with any solution. This is the situation our political system finds itself in today, as the system has become inundated with cash from corporations and wealthy donors, drowning out the voices of ordinary constituents.

Ultimately, of course, Mickey was rescued by the Sorcerer, who returned in the nick of time to restore order. So, who is the Sorcerer in our analogy? It is We the People. The Constitution, enacted by We the People, is the supreme law of the land.

Properly understood, it can lead us out of the flawed metaphor that corporations are people.

The "corporations are tools" metaphor works for many purposes. Let's return to the Santa Clara County case briefly. That case was all about taxing fences. ${ }^{120}$ In other words, it dealt with the property rights of the artificial entity known as a corporation. Corporations were designed specifically to help humans gather property and manage property rights at scale, so using the "corporations are tools" metaphor would lead to the same result that the "corporations are people" metaphor actually did. 121

120 See supra notes at 27-30 and accompanying text.

121 Justice Rehnquist, in his dissent in Bellotti, also recognizes this distinction:

There can be little doubt that when a State creates a corporation with the power to acquire and utilize property, it necessarily and implicitly guarantees that the corporation will not be deprived of that property absent due process of law. Likewise, when a State charters a corporation for the purpose of publishing a newspaper, it necessarily assumes that the corporation is entitled to the liberty of the press essential to the conduct of its business.

435 U.S. 765, 824 (1978) (Rehnquist, J., dissenting). He concludes, however, that the right of political speech is not so "essential to the conduct" of a 
I am not arguing that corporations are inherently evil. They are useful tools in helping us order our economic lives. They were designed to allow us to raise large amounts of capital to do great things (like build the transcontinental railroad). But we the people, who created corporations to serve us, have the right to limit those tools to their intended purposes. We should not endow them more generally with rights that really belong just to human beings. Corporations are not people; they are tools. And money is not speech; it is a megaphone. Any effort to give a megaphone to an inanimate tool is likely to end up like Mickey's effort to save work by endowing a broom with the power to carry water.

So let's keep using the tool of the corporation for what it was designed for. ${ }^{122}$ But let us prohibit their use for things they are ill-suited to accomplish: political speech. ${ }^{123}$

corporation's business as to deserve protection under the First Amendment. Id. at 825 .

${ }^{122}$ Cf. Trustees of Dartmouth College v. Woodward, 17 U.S. 518, 636 (1819) (“A corporation is an artificial being, invisible, intangible, and existing only in contemplation of law. Being the mere creature of law, it possesses only those properties which the charter of its creation confers upon it, either expressly, or as incidental to its very existence.").

123 Professor Greenfield has suggested that supporters of the People's Rights Amendment (discussed in more detail infra Part V) are trying to reconcile their proposed amendment with corporate rights by allowing corporations to use legal processes to protect their property (what he calls "property standing") and the right to derivatively assert the interests of its shareholders (what he calls "derivative standing"). GREENFIELD, supra note 25, at 13-18. While I agree with him that "derivative standing" is problematic since it seems to allow disregard of the corporate form in ways that might become troublesome, $i d$. at 18 , the concept of "property standing" is consistent with the "corporation is a tool" metaphor, since property rights (and their legal protection) are the essence of what the corporate form is designed to accomplish.

Professor Greenfield argues that giving corporations limited rights of political speech may still be necessary:

"Corporations should receive those speech rights necessary in order to achieve their institutional and social role. That is, corporations as a class of institutional speakers should be able to speak on the questions that arise about that role, and individual 
There are certainly cases on the margins where simply changing the metaphor might have unintended consequences. The example which comes immediately to mind is the case of a media corporation, which is in fact designed to "speak." How can one limit the right of The New York Times (or even, for that matter, the Fox News Network) to speak out on political issues?

A thorough examination of this vexing question is beyond the scope of this article. ${ }^{124}$ However, one answer might lie in the fact that such organization have speech rights deriving from an entirely different clause of the First Amendment, which separately guarantees the rights of freedom of speech and freedom of the press. Business corporations, which have no viable claim as members of the "press," likewise have no viable claim that they are designed for the purpose of engaging in political speech.

Another situation on the margins is that of corporate criminal responsibility. If a corporation is a person, it can be subjected to criminal liability just as a person is. ${ }^{125}$ If, however, a corporation is merely a tool, can you convict a tool of criminal wrongdoing? While that would seem odd, the solution may be simple. Just as guns (which are tools) don't kill people (people do), corporations (another sort of tool) don't commit crimes: its agents

corporations should be able to speak on matters that are germane to their own business."

$I d$. at 135 . While there are some blurry lines suggested by his analysis, the problem can still be resolved within the "corporations are tools" framework.

${ }^{124}$ For an interesting and thorough discussion of the implications of speech and corporate purpose, see id., at 134-170.

125 See, e.g., N.Y. Cent. \& Hudson R.R. Co. v. United States, 212 U.S. 481, 49697 (1909) (holding that a statute imposing criminal sanctions upon a corporation is constitutional). There are, of course, live questions about the reach of certain procedural rights to corporate actors. See Hale v. Henkel, 201 U.S. 43 (1906) (holding that corporations may not assert a privilege against self-incrimination under the Fifth Amendment); accord Braswell v. United States, 487 U.S. 99, 105 (1988). 
(officers, board members, employees) do. Just as the person using the gun to kill another can in many cases be prosecuted, the corporate agents who directed the criminal activity can be prosecuted. ${ }^{126}$ In fact, in some situations visiting punishment on the human actors who authorized the criminal conduct may be preferable to punishing the entire corporation, many of whose constituents may be innocent of any wrongdoing.

\section{b. Money is a megaphone}

Of course, simply declaring that corporations are tools with no political speech rights does not solve the whole problem. Simply changing that metaphor does not prohibit the wealthy individuals who profit from corporate activity from spending money distributed to them from the corporation (or acquired in other ways) to advance whatever political message or candidate they prefer. In that case, it is not the corporation speaking at all; it is a human being speaking with his or her own voice. But should those human "voices" be so loud as to drown out the many smaller voices of individuals of limited means? To what extent has the principle of "one person, one vote" 127 been replaced with "one dollar, one vote?"

If "money is speech" is seen as a metaphor, people with more money have more speech rights than people with less money. Viewing money as a megaphone solves the problem. Megaphones suggest nuisances that we are comfortable

${ }^{126}$ I am well aware that this is an oversimplification of a very complex and often controversial area of corporate and criminal law; see, e.g., W. Robert Thomas, Incapacitating Criminal Corporations, 72 VAND. L. REV. 905 (2019); John C. Coffee Jr., "No Soul To Damn: No Body To Kick”: An Unscandalized Inquiry into the Problem of Corporate Punishment, 79 MICH. L. REV. 386 (1981); Mihailis E. Diamantis, Clockwork Corporations: A Character Theory of Corporate Punishment, 103 IowA L. REV. 507 (2018); Samuel W. Buell, The Blaming Function of Entity Criminal Liability, 81 IND. L.J. 473 (2006). A full development of this problem is beyond the scope of this Article. My point here is simply that viewing corporations as tools does not necessarily preclude criminal liability for the individuals who use those tools to commit crimes.

127 See Baker v. Carr, 369 U.S. 186 (1962). 
regulating. Judge Wright's invocation of the "sound truck" metaphor seems correct. ${ }^{128}$ If we can regulate sound trucks from blaring political messages while driving around residential neighborhoods at 2 a.m., we should also be permitted to regulate the vast sums of money spent on political advertising that crowds out opposing voices or points of view. Ordinary citizens don't have sufficient money to make their opposing voices heard, and should not be compelled to spend their money in that way.

\section{The first step to solution: a constitutional amendment}

Changing the twin metaphors of "corporations are people" and "money is speech" to "corporations are tools" and "money is a megaphone" would solve the problem of corporate interference in human politics. And Stephen Pinker's suggestion that people can overcome old metaphors and replace them with better ones ${ }^{129}$ gives us some hope that the new metaphors might take hold in the law. But that remedy requires the Supreme Court to reverse nearly 200 years ${ }^{130}$ of inexorable movement toward the current state of legal affairs. And even if it did, there would be no guardrail to prevent a future Court, with different personnel, to return to the old, problematic metaphors. ${ }^{131} \mathrm{~A}$ more reliable (and

128 Wright, supra note 39, at 1006.

129 See supra notes 96-98 and accompanying text.

130 See generally WINKLER, supra note 1.

131 Sadly, but perhaps inevitably, the Supreme Court has become a political branch of government, subject to the whims of the Presidents who appoint Justices and the Senates which confirm them. Retired Seventh Circuit judge Richard Posner has pointed out that, the more the Supreme Court takes on big constitutional questions, the more it becomes a "political court":

A court is supposed to be tethered to authoritative texts, such as constitutional and statutory provisions, and to previous judicial decisions; a legislature is not--it can roam free. But the Supreme Court, when it is deciding constitutional cases, is political in the sense of having and exercising discretionary power as capacious as a legislature's. It cannot abdicate that power, for there is nothing on which to draw to decide constitutional cases of any novelty other than 
permanent) solution therefore would be for We the People to enact an Amendment to the U.S. Constitution to ensure that political rights belong only to natural human beings. ${ }^{132}$

There is a growing effort underway nationwide to do just this. Non-profit organizations such as American Promise, 133 WolfPAC, ${ }^{134}$ Free Speech for People, ${ }^{135}$ End Citizens United, ${ }^{136}$ Take Back Our Republic, ${ }^{137}$ and others are organizing citizen-led efforts to persuade Congress to propose an amendment to the Constitution to declare that political rights belong to human

discretionary judgment. To such cases the constitutional text and history, and the pronouncements in past opinions, do not speak clearly. Such cases occupy a broad open area where the conventional legal materials of decision run out and the Justices, deprived of those crutches, have to make a discretionary call.

Constitutional cases in the open area are aptly regarded as "political" because the Constitution is about politics and because cases in the open area are not susceptible of confident evaluation on the basis of professional legal norms. They can be decided only on the basis of a political judgment, and a political judgment cannot be called right or wrong by reference to legal norms.

Richard A. Posner, Foreword: A Political Court, 119 HARV. L. REv. 31,40 (2005).

${ }^{132}$ Some scholars argue that remedial measures short of a constitutional amendment might succeed, and would be easier to accomplish. For example, Professor Morrissey suggests that more robust disclosure requirements, or requiring advance shareholder approval of electioneering expenditures, might solve the problem. Morrissey, supra note 56, at 823-828. I remain skeptical, however, that disclosure requirements would survive a Citizens United analysis, or that shareholder approval would be effective given the extremely weak control that shareholders actually can exercise.

${ }^{133}$ AMERICAN Promise, www.americanpromise.net/ (last visited Dec. 27, 2019).

134 WOLF-PAC, www.wolf-pac.com/ (last visited Dec. 27, 2019).

135 FREe SPEECH FOR PEOPLE, www.freespeechforpeople.org (last visited Dec. $27,2019)$.

136 END CiTiZEns United, www.endcitizensunited.org/ (last visited Dec. 27, 2019).

137 TAKe BACK OUR REPUBLIC, www.takeback.org (last visited Dec. 27, 2019). 
citizens and not to corporate ones. ${ }^{138}$ As of this writing, 20 states have called on Congress to propose such an amendment; 139 five states have called for a limited Article $\mathrm{V}$ convention to propose such an amendment. ${ }^{140}$

The exact wording of what such an amendment would say is, of course, up to whichever group (Congress or an Article V convention of states) proposes the amendment. Efforts have begun to propose language. For example, several bills introduced in the 114th Congress propose different variations on the language. ${ }^{141}$ Some of the activist groups working on the issue

138 Some of these groups, most notably Wolf-PAC, go one step farther and call for a convention of states called pursuant to Article V of the Constitution for the limited purpose of proposing that amendment, in the belief that Congress, being captured by the monied interests, is unlikely to propose the amendment itself. See The Solution, WOLF-PAC, www.wolf-pac.com/the_solution (last visited Dec. 27, 2019).

139 The states that have adopted resolutions calling for an amendment to overturn Citizens United are California, Colorado, Connecticut, Delaware, Hawaii, Illinois, Maine, Maryland, Massachusetts, Montana, New Jersey, Nevada, New Hampshire, New Mexico, New York, Oregon, Rhode Island, Vermont, and Washington. State Resolutions in Support of Amending the Constitution, FREE SPEECH FOR PEOPLE, www.freespeechforpeople.org/stateresolutions-in-support-of-amending-the-constitution/ (last visited Dec. 27, 2019). Of those states, three have done so through citizen initiative: Colorado, Montana, and Washington. Id. The remainder have done so by resolution adopted by the state legislature, or by letters signed by a majority of members of the state legislature. $I d$.

140 The five states calling for an Article V convention to propose the amendment are, in order of their calls: Vermont, California, Illinois, New Jersey, and Rhode Island. The Solution, WOLF-PAC, www.wolfpac.com/the solution (last visited Dec. 27, 2019). Note that all five of these states are also included in the list of 19 states that have called on Congress to propose the amendment, FREE SPEECH FOR PEOPLE, supra note 139.

${ }^{141}$ For example, H.R.J. Res. 31, 115th Cong. (2017), which had 139 co-sponsors in the House, proposed adding this amendment to the U.S. Constitution:

Section 1. To advance democratic self-government and political equality, and to protect the integrity of government and the electoral process, Congress and the States may regulate and set reasonable 
have also begun efforts to propose language that either Congress or a convention might adopt. ${ }^{142}$ Regardless of how the amendment gets proposed, three-quarters of the states (38) must then ratify the amendment, by whatever process Congress or the convention specifies. ${ }^{143}$

Such an amendment, if adopted, would not automatically solve the problem, of course. It only creates space for Congress and the state legislatures to enact meaningful campaign finance reform, without the fear of the Supreme Court stepping in to overrule that legislation. ${ }^{144}$ The contours of any future legislation are therefore highly speculative at this point. However, one would hope that future Congresses and state legislatures would be responsive to the expressed will of a large majority of their

limits on the raising and spending of money by candidates and others to influence elections.

Section 2. Congress and the States shall have power to implement and enforce this article by appropriate legislation, and may distinguish between natural persons and corporations or other artificial entities created by law, including by prohibiting such entities from spending money to influence elections.

Section 3. Nothing in this article shall be construed to grant Congress or the States the power to abridge the freedom of the press.

Id. The same language was proposed on the Senate side in S.J. Res 8, and garnered 42 co-sponsors. S.J. Res. 8, 115th Cong. (2017). Several other resolutions proposing similar language but with far fewer co-sponsors were also introduced. None were adopted before the session ended.

${ }_{142}$ See, e.g., Writing the $28^{\text {th }}$ Amendment Interactive Town Hall Series, AMERICAN PROMISE, https://www.americanpromise.net/take-action/join-aprogram/writing-the-28th-amendment/_last visited Dec. 27, 2019).

143 U.S. CONST., art. V.

144 The ultimate holding of Citizens United, after all, was to declare unconstitutional the portion of the Bipartisan Campaign Finance Reform Act (commonly known as McCain-Feingold) which imposed restrictions on corporate independent expenditures. Citizens United v. FEC, 558 U.S. 310, 371-72 (2010). 
human constituents that the corrupting influence of money in politics must be eradicated.

Results from the recent mid-term elections give us hope that this might occur. In 2018, eight states either passed by citizens' initiative campaign finance reform measures, or defeated laws that would have weakened them. ${ }^{145}$ The advocacy group End Citizens United reports that forty-eight newly-elected members of Congress ran on platforms pledging to reject all contributions from corporate PACs. ${ }^{146}$ And on the first day of the 116th Congress, those newly-elected members of Congress introduced H.R. 1, the For the People Act. The comprehensive Act says its purpose is "[t]o expand Americans' access to the ballot box, reduce the influence of big money in politics, and strengthen ethics rules for public servants, and for other purposes."147

Perhaps we have reached a tipping point where campaign finance (and other good-government) reforms are capturing the imagination of voters, and meaningful reform is possible. Thinking of corporations as tools, and money as a megaphone, can help de-mystify these complex legal issues.

\footnotetext{
145 Many states pass campaign finance reform measures during midterms, THE CENTER FOR RESPONSIVE POLITICS (Nov. 7, 2018), https://www.opensecrets.org/news/2018/11/states-pass-campaign-financereform-18/.

146 Press Release, End Citizens United, With Last Race Called, 48 No Corporate PAC Candidates Are Headed To Congress (Nov. 28, 2018), https://endcitizensunited.org/press-releases/last-race-called-48-no-corporatepac-candidates-headed-congress/.

${ }^{147}$ For the People Act of 2019, H.R. 1, 116th Cong. (2019).
} 